\section{LINEN INDUSTRY RESEARCH ASSOCIATION}

\section{ANNUAL REPORT}

$\mathrm{T}$ HE report of the Council of the Linen Industry Research Association (from the Association, Lisburn, Northern Ireland) for the year ended September 30, 1946, records that the whole of the linen industry and trade in Northern Ireland are now members of the Association, which has thus become fully representative on a purely voluntary basis. The rate of subscription paid by each individual member has also substantially increased, and the Association has qualified for the maximum possible grants from the Department of Scientific and Industrial Research and the Government of Northern Ireland. Some additions have already been made to the staff, but in building up a strong, well-qualified body of workers, the Association is in competition with other demands for the limited number of new science graduates available. A good proportion of the Association's staff is trained by the Association, and during the year the value of the Association's scholarship open to first-class honours graduates in science of the Queen's University, Belfast, was considerably increased. Plans have been considered for a new technological building, but this is not expected to be completed for some time.

In pursuance of the new arrangements for keeping members in touch with the latest developments at the Institute, heads of departments are now visiting the individual Scottish members of their section twice yearly. The director and head of the Chemistry Department were members of the linen industry investigating mission in Germany during June-July 1946, and the director of research is also a member of the Flax Committee and chairman of its Flax Utilization Sub-Committee. Referring to the large reduction in acreage under flax in Northern Ireland in 1945 and 1946, the Council in its report emphasizes the urgency of research in making the growing of flax more economical in view of this increased dependence on foreign supplies of flax.

Research work noted in the report includes the statistical analysis of records of soil conditions and yields of crops, seed and fibre during 1941-44; studies to determine the effect of time of pulling on retting behaviour and on yield and quality of fibre, and spinning tests of lots of flax from the 1944 crops. An attempt has been made to devise a more objective test than the usual pull-off test for determining the end-point of retting, and an investigation of the causes of low yields with turbine scutching machines has shown that improved yields may be obtained by suitable pre-breaking and proper positioning of the grip by the feed on the conveyor belt and by modification of the beaters. The fifty per cent average loss of efficiency of clean fibre extraction is attributed to factors causing breakage of the fibre strands or straw. Data obtained in an investigation of the relation between fibre qualities and yarn quality have already thrown light on important technical problems.

The hot-air drying of flax yarn in hank form and the levelness of rayon staple yarns spun on flax machinery have also been investigated. Weaving research has centred on the performance of warp stop motions on looms, modifications to looms and methods of weaving to reduce warp breaks and improve cloth quality, and efficiency surveys in factories.

Work on dyeing and bleaching has aimed at increasing efficiency and improving quality, and particularly at securing the maximum fastness to laundering. In finishing studies, particular attention has been directed to crease-resistant treatments, and work on the proofing of canvas fabrics against attack by various agencies has continued.

\section{ANTIBIOTIC ACTION OF AN EXTRACT OF GALLERIA MELLONELLA*}

\author{
By PRof. H. R. OLIVIER
}

TARVA of Galleria mellonella are selected in their 1 adult state a little before they begin to form their cocoons. Ground up and the chitinous cuticle filtered off, they are extracted with acetone. This extract is washed three times with $N / 10$ sodium hydroxide. The three liquors thus obtained are freed of acetone, neutralized to $p H \mathbf{H} \cdot \mathbf{5}$, and each is concentrated so that 1 c.c. corresponds to $1 \mathrm{gm}$. of larval bodies.

Tubes containing 10 c.c. of glycerinated veal broth are then inoculated with 0.1 c.c. of a four-day culture of the homogeneous tubercle bacillus of Arloing and Courmont, and to these are added increasing quantities of the extracts of Galleria mellonella. The accompanying table shows one of our experiments, the dosages I, II and III representing the successive extractions of the original acetone extract.

\begin{tabular}{|c|c|c|c|c|c|c|c|}
\hline & Date & 4th & 6th & 8th & 10th & 12 th & $\begin{array}{c}\text { Lysis } \\
\text { experiment }\end{array}$ \\
\hline & Control & ++ & ++ & ++ & ++ & ++ & \\
\hline I & 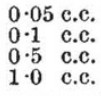 & $\begin{array}{l}+- \\
= \\
=\end{array}$ & $\begin{array}{l}+ \pm \\
+ \\
=\end{array}$ & $\begin{array}{c}++ \\
+ \\
\pm\end{array}$ & $\begin{array}{c}++ \\
+ \\
+ \\
+\end{array}$ & $\begin{array}{c}++ \\
+ \\
+\end{array}$ & $\begin{array}{l}\text { Bacilli of } \\
\text { normal aspect }\end{array}$ \\
\hline II & $\begin{array}{l}0.01 \text { c.c. } \\
0.1 \\
0.5 \text { c.c. } \\
\text { c.c. }\end{array}$ & $\begin{array}{l}+ \\
+ \\
+-\end{array}$ & $\begin{array}{l}++ \\
+ \\
+-\end{array}$ & $\begin{array}{l}++ \\
+ \\
+-\end{array}$ & $\begin{array}{l}++ \\
++ \\
+-\end{array}$ & $\begin{array}{l}++ \\
++ \\
+\end{array}$ & $\begin{array}{l}\text { Bacilli of } \\
\text { normal aspect }\end{array}$ \\
\hline III & $\begin{array}{l}0.01 \text { c.c. } \\
0.1 \text { c.c. } \\
0.5 \quad \text { c.c. }\end{array}$ & $\begin{array}{c}\text { Sub- } \\
\text { tilis } \\
- \\
-\end{array}$ & $\bar{z}$ & $\begin{array}{l}\text { Sub- }_{\text {tilis }}^{+} \\
\text {the }\end{array}$ & + & + & $\begin{array}{l}\text { Bacilli clump- } \\
\text { ed, badly } \\
\text { staining, and } \\
\text { of ill-defined } \\
\text { contour }\end{array}$ \\
\hline
\end{tabular}

In all our experiments the extracts have begun to show activity at a dosage of $0 \cdot 1$ c.c. If, by analogy with our experiments with 'Endosubtilysine', this is taken as a unit of activity, our extract has an action against the bacillus of Arloing and Courmont corresponding to 30 units per gm. of larval bodies.

We then added to 2 c.c. of a homogeneous culture of the bacillus of Arloing and Courmont, five days old, 1 c.c. of each of the three alkaline liquors I, II and III. After forty-eight hours incubation the mixtures were centrifuged and the deposit stained by the Ziehl method and examined. The bacilli were greatly altered by liquor III, staining badly, and being thickened and ill-defined in contour.

Conclusions. The larvæ of Galleria mellonella contain a substance extractable with acetone and possessing an antibiotic action against the homogeneous tubercle bacillus of Arloing and Courmont. In high concentration the extract appears to produce lysis in the same organism.

\footnotetext{
* Translated by Dr. James Marshall.
} 